reaction was of the same type as that seen in mice infected with Myco. johnei. These are by far the most convincing results so far reported, but they have not been confirmed by other workers and no subsequent paper by Jordan can be traced. Fite ${ }^{12}$ inoculated 154 rats, some of which were young, subcutaneously with human leprous material. Six developed a local leprous lesion after an incubation period of $17 \frac{1}{2}-18$ months, and in two of them the possibility of a spontaneous rat leprosy infection was as nearly as possible excluded. Material from two rats was inoculated subcutaneously into twelve other rats, ten of which became infected ; a second transfer resulted in uniform takes in twelve rats. Unfortunately, the possibility of these rats becoming infected with rat leprosy was not completely excluded. Tisseuil ${ }^{13}$ failed to produce progressive infection in rats inoculated subcutaneously with leprous material suspended in various excipients.

Nanoka ${ }^{14}$ failed to produce a progressive infection in young chickens inoculated in the breast muscles with leprous material, but Ota and $\mathrm{Nitto}^{7}$ claim to have carried out six consecutive passages in fowls by mixing the leprous emulsion with Kieselgühr, trypan blue and potassium iodide.

Taken together, the attempts to infect laboratory animals with leprosy are disappointing. Summarizing his results, Burnet ${ }^{15}$ states that, of thirty-five hamsters and sixty-three other animals of various speeies, only two hamsters were infected (these animals have already been described). He concludes that the exact susceptibility of the hamster to Myco. leprce is not yet known, but that it is certainly variable and probably not much greater than that of mice and rats. One feels that the results obtained by De SouzaAraugo $^{10}$ in mice and Jordan ${ }^{11}$ in rats were quite as promising as those so far obtained with hamsters.

The difficulty of infecting laboratory animals with leprosy is not surprising, because, of some hundred and forty-five experimental attempts to infect man, no fully accepted positive results have been obtained ${ }^{1}$. But leprosy also resembles Johne's disease in that there is a very long incubation period, and children are much more susceptible than adults. The Philippine Islands Leprosy Commission concluded that children are especicilly susceptible, and that for all practical purposes adults may be considered as immune (Dunham ${ }^{16}$ ). Rogers and Muir ${ }^{17}$ also say that in the control of leprosy "the protection of highly susceptible children is the key to the solution of the problem". They point out that the negative results of the experimental attempts to infect man are of little significance because they were all carried out on adults who had passed the most susceptible age period. They emphasize that in each of four cases of reported infection through vaccination, the patients were children or adolescents of the most highly susceptible age period. They also record two cases in which a child became infected as a result of thrusting a thorn or a needle into himself after it had been removed from the flesh of a leper. "These last two cases have a special significance owing to their having occurred in children of a highly susceptible age, while two such cases can hardly have both been coincidences."

In all the attempts to infect laboratory animals with leprosy, only a few workers have used 'young' animals. There have, however, been no systematic attempts to ascertain the age susceptibility of any species. The similarities between Myco. johnei and $M y c o$. leproe and the diseases they produce have been described. In view of the successful results which have been obtained by inoculating very young mice with $M y c o . j o h n e i$, it is felt that an attempt to produce Myco. lepro infection by inoculating very young laboratory animals would be fully justified.

Summarizing, neither Myco. johnei nor Myco. leproe will grow on ordinary culture media; they also resemble each other in that they are largely intra-cellular parasites and produce the same type of tissue reaction. Adults, even of the naturally susceptible species, are at least partially resistant to Johne's disease and leprosy, and in both there is a long incubation period. Attempts to produce either of these diseases in laboratory animals have not generally been successful. Mice have now been infected with Myco. johnei by inoculating them when very young, and it is concluded that an attempt to produce Myco. leproe infection by inoculating very young laboratory animals might meet with success.

${ }^{1}$ Francis, J., J. comp. Path., 53, 140 (1943).

${ }^{2}$ McKinley, E. B., Int. J. Leprosy, 7, 1 and 217 (1939).

${ }^{3}$ Adler, Lancet, ii, 714 (1937).

- Burnet, E., Arch. Inst. Pasteur, Tunis, 27, 327 (1938).

5 Burnet, E., and Jadford, H., Bull. Acad. Mél. Paris, 122, 383 (1939).

${ }^{-}$De Souza-Araugo, H. C., Int. J. Leprosy, 9, 63 (1941).

"Ota, M., and Nitto, S., Int. J. Leprosy, 9, 299 (1941).

${ }^{8}$ Dhamendra and Lowe, J., Indian J. Med. Res., 28, 61 (1940).

- Burnet, E., Arch. Inst. Pasteur, Tunis, 29, 174 (1940). ${ }^{10} \mathrm{De}$ Souza-Araugo, H. C., Trans. Roy. Soc. Trop. Med. Hyg., 24,

${ }^{11}$ Jordan, P., Arch. Schiffe-, u. Tropenhyg., 40, 92 (1936).

12 Fite, G. I., Publ. Health Rep., Wash., 56, 1919 (1941).

${ }^{13}$ Tisseuil, J., Bull. Soc. Path. Expt., 32, 542 (1939).

14 Nanoka, N., Kitasato Arch., 17, 175 (1940).

${ }^{5}$ Burnet, E., Arch. Inst. Pasteur, Tunis, 29, 155 (1940).

${ }^{16}$ Dunham, G. C., Amer. J. Publ. Health, 28, 27 (1936).

17 Rogers, L., and Muir, E., "Leprosy" (Bristol: John Wright and Sons, 2nd Edit., 1940).

\section{EVOLUTION OF THE PLANETARY SYSTEM}

$\mathrm{W}$ ITHIN the last twelve months, a considerable amount of interest has been shown in theories of the origin of the planets and satellites. Two new theories have been advanced, notices of which appeared in NATURE $(150,215$, and 151, 200), and now another theory by Lieut.-Colonel K. E. Edgeworth has just been published (J. Brit. Astro. Assoc., 53,6 ; July 1943).

The author starts with a vast cloud of scattered material-gas, dust and small particles with an average diameter of $0.5 \mathrm{~cm}$.- -and assumes that this cloud was' rotating with angular velocity increasing towards the centre. Owing to inelastic collisions, random velocities were roduced and the rotating cloud became a thin disk in which there occurred an increase in local densities, instability finally taking place. Local condensations, each possessing its own rotation, were formed, but these rotations were slowed down through viscosity, and there was an increase in the central density of each condensation. In many cases these condensations broke up into smaller ones but some coalesced into a number of larger ones by their attraction, and from these larger agglomerations the planets and satellites were formed. The mechanism by which the planets were formed was not necessarily the same as that which was responsible for the formation of the sun, and different suggestions are made regarding this last point, but the author hopes that further investigation will decide which view will be most likely. 
The satellites were formed in a similar manner to the planets, the scattered material surrounding the planets forming local condensations which coalesced to form satellites. In the case of the moon and other large satellites, like Titan and Triton, it is suggested that this mechanism was not in operation, and it is thought that the moon was formed of the same primitive material as the earth. The asteroids were formed from condensations which failed to coalesce into larger agglomerations, the perturbations of Jupiter being responsible for this effect. The comets were formed in a cloud of scattered material which may still extend far beyond the orbit of Pluto. Owing to the diffuse condition of the material the condensations did not coalesce, merely condensing on self. While the asteroids developed sufficient cohesion to form solid bodies, the comets remained a mere collection of loose particles. Probably the great difference of temperature was responsible for this divergence of development.

The theory is stated in a very tentative form and a large amount of detail still remains to be developed. No doubt the author will clarify a number of points which appear to present certain weaknesses in the theory.

\section{THE MUMBWA CAVES, NORTHERN RHODESIA}

$\mathrm{T}$ HE Mumbwa caves have long been known. Yet, in spite of the fact that in South Africa prehistoric cave sites are few and far between, only now has efficient and systematic investigation been undertaken. F. Macrae, many years ago, was the first to make some trial excavations, the resulting finds from which are in the Cambridge Museum of Archæology and Ethnology, but no complete investigation was attempted. Macrae unearthed a really fine Acheulean type of coup de poing in the basal level, and this was covered by other layers containing poor Middle Stone Age industries. A characteristic feature was the number of spherical stone balls found. Now at last a detailed account of the whole section actually present has been prepared ("Further Excavations (1939) at the Mumbwa Caves, Northern Rhodesia", by J. Desmond Clark, Trans. Roy. Soc. of S. Africa, 29, Pt. III).

At once it must be remarked that the so-called furnace with iron slag said to have been found in the middle levels by a previous investigator (not Macrae) has been shown to have probably been a grave, while the 'slag' has been proved to be merely a brown cave deposit of sand and silt cemented by calcium phosphate and carbonate. Clark found no more lower palæolithic artefacts, and it would seem that the inhabitants of the Mumbwa sites in those times cannot have been numerous. Macrae was evidently lucky. Above the lowest level comes an industry called by Clark the Rhodesian Stillbay, and this in turn is overlain by a Northern Rhodesian Wilton, the whole being capped by a layer containing iron objects. The finds are well illustrated and carefully analysed, and comparisons are made with other discoveries in the region and at the classic sites.

A section on the geology of the caves has been supplied by F. E. Zeuner, and the author has had the advantage of collaborating with I. F. Schofield when describing the Iron Age culture from the uppermost layer. The article as a whole is a very useful piece of work.

\section{FORTHCOMING EVENTS}

\author{
Saturday, September 4
}

British Psychologicar Socinty (at Tavistock House, Tavistock Square, London, W.C.1), at 2 p.m.-' "On the Problem of Representative Sampling of the Population"

\section{APPOINTMENTS VACANT}

APPLICATIONS are invited for the following appointments on or before the dates mentioned:

TEACHER OF MINING SUBJECTS-The Education Officer, County Hall, Wakefleld (September 1).

eiducational Psychologist at the Chitd guidance ClinicThe Chief Education Officer, Education Offices, Northern Secondary chool, Mayfleld Road, Portsmouth (September 4).

ADVISORY MYCOLOGIST-The Secretary, North of Scotland College of Agriculture, $41 \frac{1}{2}$ Union Street, Aberdeen (September 4).

LECTURER IN ELECTRICAL ENGINEERING of Degree standard for National Certiflcate Course, at the South-East London Technica Institute, Lewisham Way, S.E.4-The Education Officer (T. 1) County Hall, Westminster Bridge, London, S.E.1 (September 4).

TEACHER FOR THE CORREOTION OF SPEECH DERECTS The Director of Education,

(September 11). HEAD OF THE DEPARTMENT OF MATHEMAT
Watt College, Edinburgh (September 20).

Watt College, Edinburgh (September 20). HEADS OF THE DEPARTMENTS OF PHYSIOLOGY, MEDICINE, AND
SURGERY - The Bursar, Royal Veterinary College and Hospital, at The University, Reading (October 1).

ChalR OF NAVAL ARCHITECTURE-The Acting Secretary of University Court, The University, Glasgow (October 4).

DIRECTOR OF ROBERT GORDON'S TEOHNICAI COLJEGE-The Secretary, Robert Gordon's Technical College, Aberdeen (October 16).

LECIURER IN ELECTRICAI ENGINEERING for part-time students taking London University Examinations to Final B.Sc. and Higher National Certiffcate standards-The Principal and Organizer of Further Education in Rugby, College of Technology and Arts, Eastlands, Rugby.

TEAchers for Evening Classes in Chemistry up to Intermediate Science standard-The Director of Education, The Polytechnic, 309 Regent Street, London, W.1.

ASSISTANT PORT HEATTH OFFTCER for the Basrah Port Directorate, Government of Iraq-The Secretary, Overseas Manpower Committee (Ref. 1034), Ministry of Labour and National Service, Alexandra House, Kingsway, London, W.C.2.

DEPUTY CHIEF CHEMIST-The General Manager, Liverpool Gas Company, Bold Street, Liverpool 1 (endorsed 'Chemist')

\section{REPORTS and other PUBLICATIONS}

\section{(not included in the monthly Books Supploment)}

\section{Great Britain and Ireland}

Medical Research Council. Special Report Series, No. 244: Chronic Pulmonary Disease in South Wales Coalminers, 2: Environmental Sudies Disease. B.-G. Reports on Physical, Chemical and Petrological Disease; B.-G. : Reports on Phr. Studies, by Dr. $T$. Bedford and Dr. C. G. War. Dr. Nagelschmidt: Briscoe, Dr. P. F. Holt, Dr. N. Spoor and others; Dr. G. Nagelschmidt; Dr. A. Brammall and Major J. G. C. Leech; D. Hicks and Dr. G. Nagelschmidt; J Tvon (raham and $\mathrm{Mr}$. Stationery Office.) 10s, $6 d$. co-workers. Pp. xi + 222. (London: L.M. Stationery Ofhce.) 10s. 64 .
[ 48 ] Met. H. A. Dade. Pp. 25. (Kew : Imperial Mycological Institute.) 38. 9d. net. Department of Scientiflc and Industrial Research. Index to the Literature of Food Investigation. Vol. 14, No. 2, September 1942. Compiled by Agnes Elisabeth Glennie, assisted by Catherine Alexander. Pp. iv +73-150. (London: H.M. Stationery Office.) 48.6d. net.

\section{Other Countries}

Report and Accounts of the National Botanic Gardens of South Africa, Kirstenbosch, Newlands, Cape (and the Karoo Garden, Whitehill, near Matjesfontein) for the Year ending 31st December 1942. Pp. 12. (Kirstenbosch : National Botanic Gardens.)
[58 for the Year ended 31st December 1942. Pp. 8. (Fntebbe : Government Printer.) 18.

ment Printer.) 18 . Fincipal Summer Weed Hosts of the Beet Leafhopper in the San Joaquin Valley, California. By F: R. Lawson and $\mathbf{R}$. $\mathbf{L}$. in the San Joashington, D.C.: Government Printing Office.) 10 cents.

\section{Catalogues}

A Catalogue of Miscellaneous Books in English History and Literature printed after 1700 , followed by a selection of Recent Purchases including the series of Chronicles and Memorials published under the direction of the Master of the Rolls, Fine Arts, Natural History, Works by William Prynne, Spr.

Bernard Quaritch, Ltd.) $3 d$.
An Improved Design of Portable Three-Cup Anemometer. (Leaflet 661.) Pp. 4 (Lnndon : C. F. Casella and Co. Ltd.) 